\title{
A META-ANALYSIS OF RANDOMIZED CONTROLLED TRIALS IN THE TREATMENT OF BACTERIAL VAGINOSIS
}

\author{
Aquartuti Tri Darmayanti ${ }^{1}$, Tri Nugraha Susilawati ${ }^{2}$, Bhisma Murti ${ }^{1}$ \\ ${ }^{1)}$ Masters Program in Public Health, Universitas Sebelas Maret \\ 2) Department of Microbiology, Faculty of Medicine, Universitas Sebelas Maret
}

\begin{abstract}
Introduction: Metronidazole is commonly used to treat bacterial vaginosis (BV) despite its various side effects and frequent cases of $\mathrm{BV}$ recurrences. This study aimed to compare the effectiveness of probiotic vs metronidazole for bacterial vaginosis.

Methods: A meta-analysis of randomized control trials (RCTs) was performed on the studies available in PubMed, Science Direct, Web of Science, Springer Link and the Cochrane databases. The meta-analysis was based on random-effects models and included studies evaluating BV therapy in women during their reproductive age. The data were analyzed using Rev Man 5 software for the heterogenity.

Results: Thirteen studies involving 2149 subjects were included in the analysis.The results of this meta-analysis showed that probiotic has a beneficial effect for the treatment of BV compared to placebo (OR: 0.62; $95 \% \mathrm{CI}=0.40-0.97)$. In addition, probiotic can reduce the risk of BV incidence by a half time compared to metronidazole (RR: $0.51 ; 95 \% \mathrm{CI}=$ $0.20-1.33)$,

Conclusion: Probiotic therapy could be used as an alternative to metronidazole therapy for bacterial vaginosis.

Keywords: meta-analysis, bacterial vaginosis, randomized controlled trial

Correspondence: Aquartuti Tri Darmayanti. Masters Program in Public Health, Sebelas Maret University, Jl. Ir. Sutami 36 A, Surakarta 57126, Central Java. Email: tutiaquar@gmail.com.

Mobile: +6281329380114.
\end{abstract}


